\title{
Associations between canopy openness, butterfly resources, butterfly richness and abundance along forest trails in planted and natural forests
}

\author{
Atsush OHWAKI, SAKI MAEDA, MAsahIKo KITAHARA and TAKASHI NAKANO \\ Division of Natural Environmental Science, Mount Fuji Research Institute (MFRI), Yamanashi Prefectural Government, 5597-1 \\ Kenmarubi, Kamiyoshida, Fujiyoshida 403-0005, Japan; e-mails: papiho@hotmail.co.jp, ohwakiat@mfri.pref.yamanashi.jp, \\ maeda.s@mfri.pref.yamanashi.jp, mkita@mfri.pref.yamanashi.jp, nakano@mfri.pref.yamanashi.jp
}

Key words. Lepidoptera, butterfly, diversity, abundance, forest structure, canopy, host plant, light conditions, nectar resource, plantation, temperate forest

\begin{abstract}
Increasing the biodiversity in plantations of trees is an important issue because plantations have replaced many natural and semi-natural ecosystems worldwide. Therefore, identifying appropriate management techniques and key factors for enhancing biodiversity in plantations is required. We surveyed butterfly assemblages along forest trails in both plantations and natural forests and measured various environmental variables, including canopy, sub canopy and shrub stem densities, percentage of deciduous trees, flower plant richness, host plant richness, canopy openness and distance to forest edge. We hypothesized that (1) flower and host plant richness increase with an increase in the percentage of deciduous trees and canopy openness; (2) butterfly richness and abundance increase with an increase in forest structural complexity, butterfly resources, canopy openness and distance to forest edge; (3) the responses of plants and butterflies to canopy openness differ in plantations and natural forests; and (4) in plantations, tree-feeding butterflies respond to canopy openness less strongly than herbaceous plant feeding butterflies do because of the low diversity of trees in plantations. Our results generally support these hypotheses. Butterfly resources and butterfly richness and abundance all increase with increasing canopy openness; however, the increases were usually more dramatic in natural forests than in plantations and other factors are less important. In plantations, herbaceous plant feeding butterflies responded to increasing canopy openness more strongly than tree-feeding butterflies. The results of the present study indicate the importance of sunlit forest trails in enhancing butterfly resources, butterfly richness and abundance in plantations. Because at the stand-level management is labour- and cost-intensive, labour- and cost-saving trail management options need to be explored further in terms their effectiveness in increasing biodiversity in plantations.
\end{abstract}

\section{INTRODUCTION}

The increase in biodiversity in plantations of trees is an important issue because plantations have replaced many natural and semi-natural forests and grasslands worldwide and the area covered by these plantations continues to increase (Brockerhoff et al., 2008; Payn et al., 2015). Because the conversion of natural forests into plantations has a great effect on the native fauna and flora (plants: Barlow et al., 2007a; Bremer \& Farley, 2008; vertebrates: Barlow et al., 2007a; du Bus de Warnaffe \& Deconchat, 2008; Yamaura et al., 2009; insects: Robertson et al., 1995; Magura et al., 2000; Barlow et al., 2007a, b; reviewed in Lindenmayer \& Hobbs, 2004; Brockerhoff et al., 2008), identification of the appropriate management techniques and key factors that enhance biodiversity within plantations is required. This is particularly important in countries where plantations occupy a large percentage of the forest area or where the area under plantations is rapidly increasing.
The conversion of natural forests into plantations changes various forest characteristics. Plantations are often planted with a single species of coniferous tree in the temperate northern hemisphere (Brockerhoff et al., 2008; Yamaura et al., 2012). In addition, the removal of understory vegetation reduces not only tree diversity but also decreases the structural complexity of plantations (Hartley, 2002; Lindenmayer \& Hobbs, 2004). Understory vegetation, woody debris and light conditions can also differ greatly from those in natural forests, depending on the age of a plantation, species of tree planted and management $(\mathrm{Na}-$ gaike, 2000; Bremer \& Farley, 2010). Several studies have revealed a high sensitivity of herbivorous and saproxylic insects to the changes associated with converting natural forests into plantations in both temperate and boreal areas. For example, the diversity of longicorn beetles (Cerambycidae) is lower in plantations than in natural forests, and positively correlated with tree diversity, forest matureness and light conditions (Martikainen et al., 2000; Maeto et 
al., 2002; Ohsawa, 2004). By contrast, the diversity of leaf beetles is higher in larch plantations than in natural forests because there is a greater understory plant diversity and a more open canopy in larch plantations (Ohsawa \& Nagaike, 2006).

Most of the studies on the effects of plantations and logging on butterflies are for the tropics and report that plantations have a lower butterfly diversity and fewer endemic species than natural forests (Barlow et al., 2007b, 2008). By contrast, the effects of logging on butterflies are inconsistent, e.g., the effects of logging on butterfly diversity can be positive (Hamer et al., 1997; Willott et al., 2000), negative (Hill et al., 1995; Hamer et al., 2003; Dumbrell \& Hill, 2005 ) or change between seasons or spatial scales (Hamer \& Hill, 2000; Hamer et al., 2005); however, the majority of these studies indicate a decline in endemics due to logging. These studies show that canopy openness, understory vegetation and forest structure are important factors in shaping butterfly assemblages in plantations and disturbed forests. Butterflies function as herbivores and pollinators and are suitable model insects for determining the effects of the conversion of natural forests into plantations and the relevant environmental changes because their identification is easy and they respond to subtle changes in the environment and can reflect the diversities and communities of other taxa (Dennis, 2004; Barlow et al., 2007a; Winfree et al., 2011; Ohwaki et al., 2017). However, in temperate areas, few studies have compared butterfly assemblages in plantations and natural forests with the aim of identifying the factors necessary for increasing butterfly diversity in plantations. This is possibly because plantations are regarded as "green deserts" (see van Halder et al., 2008).

Several studies report the importance of open spaces in increasing plant and butterfly diversity in both temperate natural forests and plantations. Large, open spaces, such as wide rides, large glades and firebreaks (wider than 15-20 m) are colonized by many species of plants and the resultant high plant richness supports endangered grassland butterflies (Warren, 1985; Greatorex-Davies et al., 1993; Sparks et al., 1996; Smith et al., 2007; van Halder et al., 2008; Berg et al., 2011; Fartmann et al., 2013). However, such large open spaces are rare and narrow forest trails are more common in many regions. Even though forest trails may not be suitable for grassland species, they can provide valuable sun-lit areas for forest species or forest edge species. This is particularly important in temperate East Asia, which has a rich forest butterfly fauna (Ohwaki et al., 2007; Kim \& Seo, 2012). However, there is variability in light conditions, from shady trails below closed canopies to sun-lit trails with open canopies or canopies with some gaps. This variability provides the opportunity to test whether improving light conditions along trails can result in an increase in butterfly diversity in plantations, as well as in natural forests. In addition, butterfly assemblages can be affected by forest structure and tree composition in temperate areas, which differs between natural forests and plantations and can be controlled via management (Taki et al., 2010; Verdasca et al., 2012). These features, therefore, should be taken into consideration.

In Japan, the increase in biodiversity in plantations is a critical issue because many natural and secondary forests have been converted into coniferous plantations. In 2012, it was estimated that plantations occupied approximately 10.3 million ha of land, which amounted to $41 \%$ of the total forested area and $27 \%$ of the national land surface (Forestry Agency Japan, 2016). The majority of plantations and secondary forests are increasingly shady because both are often unmanaged. In plantations, thinning and harvesting of wood now rarely occurs because forestry is declining as an industry in Japan (Yamaura et al., 2012). Coppicing has also ceased in secondary forests for several decades (Fukamachi et al., 2001). Forest trails are thus valuable habitats for butterflies because they are often well sun-lit areas in otherwise rather shady habitats.

We surveyed butterflies mainly along forest trails, not in forest interiors, for the following reasons. First, forest trails and edge habitats are richer in butterflies than the interior of plantations (van Halder et al., 2011). Second, in the region studied, butterflies are rare on the floor of natural forests with closed canopies (Kitahara, 2004) and the light conditions along some trails are low, almost equal to those in the interior of forests. Finally, because management aimed at increasing biodiversity at the stand-level in plantations is labour- and cost-intensive (Cummings \& Reid, 2008), concentrating on the management of trails saves time, labour and money. In the present study, we examined the effects of conversion of natural forests into coniferous plantations, canopy openness and various forest characteristics (e.g., tree stem density, diameter at breast height [DBH] of canopy trees and percentage of deciduous trees) on butterfly resources and butterfly assemblages and whether the responses of plants and butterflies to canopy openness differ between plantations and natural forests. We hypothesized that (1) numbers of nectariferous flowers and host plant diversity increase with increasing percentage of deciduous trees and canopy openness mainly due to improved light conditions resulting in the development of an herbaceous plant layer; (2) butterfly richness and abundance increase with increasing forest structural complexity (increasing sub canopy and shrub densities), butterfly resources and canopy openness; (3) the responses of plants and butterflies to canopy openness differ in plantations and natural forests (the interaction between canopy openness and plantation/natural forest) because management of plantations only slightly influences the local fauna and flora in areas where the canopy is opened up; and (4) tree-feeding species respond to light conditions less strongly than herbaceous plant feeding species in plantations because the recovery of trees may be slower than that of herbaceous plants / grass even if light conditions are improved.

\section{MATERIALS AND METHODS}

\section{Sites studied}

The sites studied were located on the northern foot of Mt. Fuji $\left(138^{\circ} 35^{\prime} 59^{\prime \prime}-54^{\prime} 26^{\prime \prime} \mathrm{E}, 35^{\circ} 23^{\prime} 44^{\prime \prime}-29^{\prime} 31^{\prime \prime} \mathrm{N} ; 30 \mathrm{~km}\right.$ from the east 
to the west, $10 \mathrm{~km}$ from the north to the south) in a cool temperate area. In this area, three types of coniferous plantations dominate, namely evergreen red pine (Pinus densiflora) at low altitudes, deciduous larch (Larix kaempferi) at a wide range of altitudes and evergreen Veitch's silver fir (Abies veitchii) at high altitudes; whereas, natural forests, including secondary deciduous forests and naturally regenerated red pine forests, are patchily distributed. We selected 16 sites between the altitudes 910 and 1550 $\mathrm{m}$, consisting of 8 plantations and 8 natural forests (including secondary forests). The plantations included two Veitch's silver fir plantations (PAB 1-2), four larch plantations (PLA 1-4) and two red pine forests in which the understory was managed and the shrubs removed (PRP 1-2), whereas the eight natural forests included four broadleaved deciduous forests dominated by Carpinus tschonoskii, Quercus crispula and/or Q. serrata (NDE 1-4), two natural conifer-broadleaved mixed forests dominated by Chamaecyparis obtusa and Tsuga sieboldii with some broadleaved trees (NMI 1-2), and two unmanaged natural red pine forests in which red pine trees were naturally regenerating (NRP $1-2)$. All forests at the study sites were older than 30 years and were larger than 3 ha (Table S1). They were often adjacent to other types of forest and were not surrounded completely by open areas (therefore, the size of the forests studied was much larger than $3 \mathrm{ha}$, if the adjacent forests were included). To avoid confounding spatial autocorrelations and forest type, the same types of forests were at least $4 \mathrm{~km}$ distant from each other and the different types of forests were separated by at least $1 \mathrm{~km}$.

\section{Butterfly counts}

At each site, one 200-m transect was established. The transects were located along forest trails at the majority of the sites (13 sites) and all transects were at least $20 \mathrm{~m}$ distant from other types of forests, roads and open areas. The forest trails surveyed were approximately 2-6 m wide. Although the branches in the canopy of the trees growing alongside the trails usually extended across the trails regardless of their width, canopy openness varied between transects depending on tree density and existence of natural or artificial gaps. At three sites where there were no trails (PLA 1, PLA 4, and PRP 2), one 200-m transect was established in the interior of the forest. Walking along the transects at a steady pace, all the butterflies observed within $2.5 \mathrm{~m}$ on either side and $5 \mathrm{~m}$ at the front were identified and counted (Pollard \& Yates, 1993). Butterfly behaviour was also recorded as either; feeding, mating, ovipositing, flying (including searching behaviour), and resting (including basking and territorial behaviour). Butterfly surveys were carried out six times from June to October in 2015 and twice from April to May in 2016 (a total of eight surveys) between 09:30 and 16:00 $\mathrm{h}$ when the weather was suitable: wind speeds of three or less on the Beaufort scale. During June to early September, surveys (five times per site) were carried out when air temperature was always $23^{\circ} \mathrm{C}$ or higher, and during early spring (April-May) and late autumn (late September-early October), surveys were always carried out in sunny weather if the air temperature was $19-20^{\circ} \mathrm{C}$. Such weather conditions are suitable for monitoring butterflies (Wikström et al., 2009). The sites at high altitudes were surveyed later in the year except in late autumn because seasons occur later at these altitudes. During June-August, when adult hairstreak butterflies were active, the branches of trees below $7.5 \mathrm{~m}$ above the ground were beaten in order to detect them. Pieris melete and P. nesis were recorded as a single species, Pieris $m / n$, because it is difficult to distinguish between them in the field.

The butterfly species recorded were classified into herbaceous plant feeders (including grass feeders) or tree feeders based on their larval host plants (Table S2). Species whose larvae feed on both herbaceous plants and trees or feed on bamboo were not classified into either group.

\section{Vegetation survey, canopy openness and other variables}

At each site, three different types of surveys of the vegetation were carried out. First, four $20 \mathrm{~m} \times 5 \mathrm{~m}$ quadrats were established on both sides of the transects (two quadrats in the first $100 \mathrm{~m}$ and two in the second $100 \mathrm{~m}$ along the transects). The longer side (20 $\mathrm{m})$ of the quadrat was set parallel to the edge of the trail. The trails themselves were not included in the quadrats because we were only interested in the characteristics of the forest surrounding the trails and because the width of the treeless trails would affect the tree density recorded in the forests if trails were included. All woody stems $\geq 2 \mathrm{~cm}$ in diameter at breast height $(\mathrm{DBH})$ were identified to species and their DBH and height determined between June 29 to October 1, 2015. Tree stems of $12 \mathrm{~m}$ or taller were included in the canopy, stems of 6.5-11 m height in the sub canopy, and stems of $6 \mathrm{~m}$ or less in the shrub layer. All sites, except for one Veitch's silver fir site (PAB 1: $10 \mathrm{~m}$ in canopy height), had a canopy layer. From the quadrat survey, forest structural variables (canopy stem density, sub canopy stem density, shrub stem density, and mean canopy DBH) and tree diversity / compositional variables (tree species richness, percentage of coniferous trees and percentage of deciduous trees) were calculated. The canopy, sub canopy and shrub stem densities were expressed as the sum of stems from the four quadrats in each stratum. The mean canopy DBH was the average of the DBHs of the canopy stems recorded in the four quadrats. Because PAB 1 lacked a canopy layer, canopy DBH at this site was calculated from the average of the DBH of the stems with a $10-\mathrm{m}$ height. Tree species richness was the number of tree species recorded in the four quadrats. The percentages of the coniferous and deciduous trees were the percentages of stems of coniferous and deciduous trees in the canopy and sub canopy layers, respectively. The percentage of coniferous trees was measured because no butterflies in this region feed on coniferous trees and we expected this to be negatively associated with butterfly richness. The percentage of deciduous trees was measured because deciduous trees affect light conditions on the forest floor and in understory vegetation, which in turn affect butterfly resources and butterfly distributions (van Halder et al., 2008).

Second, all the flowering species of plants, excluding the graminoids (Poaceae, Cyperaceae and Juncaceae), and their abundances were recorded within $1.5 \mathrm{~m}$ on both sides of the whole transect on the same date as the butterfly surveys, except in June (that is a total of six times). The abundance of flowers of each species was scored in three ranks: 1: 1-9 occurrences of a species of plant growing singly or occupying less than $10 \mathrm{~m}^{2} ; 2$ : 10-99 occurrences or occupying 10-99 $\mathrm{m}^{2}$; and 3: greater than 100 occurrences or occupying more than $100 \mathrm{~m}^{2}$. The species of flowering plants utilized by adult butterflies were selected based on the field experience of the first author and primary literature (Fukuda et al., 1982-1984). In this survey, the richness of flowering plants and flower abundance were calculated for each transect (site). The richness of flowering plants was expressed as the number of species of flowering plants utilized by adult butterflies throughout the survey. The abundance of flowers was expressed as the sum of the abundance scores for each species throughout the survey.

Third, all the species of seed plants along the transects were recorded once in the period between June 30 to September 15, 2015. Species of shrubs less than $2 \mathrm{~m}$ in height and herbaceous plants growing within $1.5 \mathrm{~m}$ of the transects and species of trees taller than $2 \mathrm{~m}$ growing within $5 \mathrm{~m}$ of the transects were recorded. Because of the limitations on identifying graminoids, the records for species of graminoid were restricted to seven species. By 
combining the species of plants recorded in the three types of vegetation surveys, the number of species host plants (host plant richness) was obtained from the host plant list of Japanese butterflies (Saito et al., 2016).

Another environmental variable that might influence the distribution of butterflies is light intensity, which was measured in terms of canopy openness. Hemispherical photographs were taken along the transects at 10 points, every $20 \mathrm{~m}$ after the first 10 $\mathrm{m}$ of the transect, at a height of $130 \mathrm{~cm}$ during the growing season (June 30 - July 28, 2016), using a fisheye lens (camera: Stylus TG-4 Tough, Olympus Corporation, Tokyo, JP; fisheye lens: UWC-0195, FIT Co., Nagano, JP). The canopy openness was then calculated from the hemispherical photographs using CanopOn 2 software (http://takenaka-akio.org/etc/canopon2/index. $\mathrm{html}$ ). Along each transect, light conditions varied and butterflies were not evenly distributed (i.e., more butterflies were observed in areas where the light intensity was highest). Therefore, we used the average value recorded at the five points where canopy openness was greatest, instead of the average value for all ten points. We also measured two landscape variables, altitude and distance to forest edge from the centre of each transect. Distance to forest edge was measured because forest edge can be a source of butterflies (Ohwaki et al., 2007; van Halder et al., 2011). Forest edge was defined as a boundary between a forest and open vegetation of $\geq 0.1$ ha or between a forest and strips of herbaceous roadside vegetation, $2-3 \mathrm{~m}$ wide along local roads.

\section{Data analysis}

The following 14 variables were recorded in the surveys mentioned above: canopy stem density, sub canopy stem density, shrub stem density, mean canopy DBH, tree species richness, percentage of coniferous trees, percentage of deciduous trees, flower plant richness, flower abundance, host plant richness, canopy openness, forest type (plantation or natural forest), altitude and distance to forest edge. We first checked for correlations among the explanatory variables using a Pearson's correlation matrix and a principal component analysis, which indicated that many explanatory variables were correlated with each other (Table S3 and Fig. S1). Therefore, we removed several explanatory variables before using generalized linear models (GLMs) by calculating the variance inflation factor (VIF), which helped determine the severity of multicollinearity by indicating which variables were highly correlated (VIF $>5-10$ ), and therefore, were not included in the GLMs (Zuur et al., 2007). In the present study, because we focused on forest type and canopy openness, these variables were always included, whereas other variables with VIFs $>6$ were removed. Consequently, for the GLMs of butterfly resources (e.g.,
Table 1. Results of the GLMs with a Poisson error distribution that were used to analyse flower plant richness and flower abundance. The explanatory variables are standardized. The coefficients for forest type and the interaction between canopy openness*forest type are shown as differences from the values recorded in the natural forests.

\begin{tabular}{|c|c|c|c|c|}
\hline & \multicolumn{2}{|c|}{ Flower plant richness } & \multicolumn{2}{|c|}{ Flower abundance } \\
\hline & Coeff. (SE) & $P$ & Coeff. (SE) & $P$ \\
\hline \multicolumn{5}{|l|}{ Explanatory variables } \\
\hline Canopy stem density & - & & - & \\
\hline Canopy DBH & - & & - & \\
\hline Tree species richness & - & & - & \\
\hline$\%$ deciduous trees & - & & $0.263(0.101)$ & 0.02 \\
\hline Canopy openness & $2.229(0.706)$ & 0.008 & $1.985(0.657)$ & 0.0 \\
\hline Forest type (plantation) & $-0.537(0.369)$ & 0.171 & $-0.117(0.324)$ & 0.7 \\
\hline Openness*forest type & $-1.835(0.716)$ & 0.025 & $-1.503(0.663)$ & 0.04 \\
\hline Altitude & - & & - & \\
\hline Distance to forest edge & - & & - & \\
\hline Degree of freedom & 3,12 & & 4,11 & \\
\hline Pseudo $\mathrm{R}^{2 *}$ & 0.676 & & 0.856 & \\
\hline Model & Quasi-GLM & & Quasi-GLM & \\
\hline$\varphi$ & 3.124 & & 3.249 & \\
\hline
\end{tabular}

*Pseudo $\mathrm{R}^{2}$ : (null deviance-residual deviance)/null deviance.

flower plant richness, flower abundance and host plant richness), the following nine explanatory variables were tested: canopy stem density, canopy DBH, tree species richness, percentage of deciduous trees, canopy openness, forest type (natural or plantation), altitude, distance to forest edge and the interaction between canopy openness and forest type (Tables 1-2), and for the GLMs of butterfly richness and abundance, the following nine explanatory variables were tested; canopy stem density, shrub stem density, canopy DBH, percentage of deciduous trees, total host plant richness, canopy openness, forest type (natural or plantation), distance to forest edge, and the interaction between canopy openness and forest type (Tables 3-4).

We developed GLMs, assuming a Poisson error distribution, in order to identify how butterfly resources (e.g., flower plant richness, flower abundance and host plant richness) and butterfly richness and abundance were associated with the above nine environmental variables. Host plant richness was also analyzed separately for tree and herbaceous plants. Butterfly richness and abundance were analyzed separately for tree-feeding and herbaceous plant feeding species. In the GLMs of tree- and herbaceous plant feeding species, tree and herbaceous host plant richness were utilized as the host plant richness variables. The model selection process was backward stepwise and the models with the lowest Akaike Information Criterion (AIC) were selected. Then, we checked the dispersion parameter of the models. If the dispersion parameter $\varphi$ (residual deviance divided by residual degree of

Table 2. Results of the GLMs with a Poisson error distribution used to analyse species richness of all host plants, tree host plants and herbaceous host plants. The explanatory variables are standardized. The coefficients for forest type and the interaction between canopy openness ${ }^{\star}$ forest type are shown as differences from the values recorded in the natural forests.

\begin{tabular}{|c|c|c|c|c|c|c|}
\hline & \multicolumn{2}{|c|}{ Total host plant } & \multicolumn{2}{|c|}{ Tree host plant } & \multicolumn{2}{|c|}{ Herbaceous host plant } \\
\hline & Coeff. (SE) & $P$ & Coeff. (SE) & $P$ & Coeff. (SE) & $P$ \\
\hline \multicolumn{7}{|l|}{ Explanatory variables } \\
\hline Canopy stem density & - & & - & & - & \\
\hline Canopy DBH & $0.170(0.062)$ & 0.060 & - & & $0.492(0.206)$ & 0.036 \\
\hline Tree species richness & $0.302(0.068)$ & $<0.001$ & $0.156(0.061)$ & 0.010 & - & \\
\hline$\%$ deciduous trees & - & & - & & - & \\
\hline Canopy openness & $0.354(0.082)$ & $<0.001$ & - & & $2.966(0.649)$ & $<0.001$ \\
\hline Forest type (plantation) & - & & - & & $-1.137(0.382)$ & 0.012 \\
\hline Openness*forest type & - & & - & & $-2.373(0.656)$ & 0.004 \\
\hline Altitude & - & & - & & - & \\
\hline Distance to forest edge & - & & -0.104 & 0.118 & - & \\
\hline Degree of freedom & 3,12 & & 2,13 & & 4,11 & \\
\hline Pseudo $\mathrm{R}^{2 *}$ & 0.617 & & 0.596 & & 0.689 & \\
\hline Model & Poisson GLM & & Poisson GLM & & Quasi-GLM & \\
\hline$\varphi$ & 1.204 & & 0.524 & & 2.145 & \\
\hline
\end{tabular}

* Pseudo R²: (null deviance-residual deviance)/null deviance. 
Table 3. Results of the GLMs with a Poisson error distributions used to analyse the total butterfly richness and abundance, respectively. The explanatory variables are standardized. The coefficients and SE of the environmental variables for the most parsimonious models are shown. The coefficients for forest type and the interaction between canopy openness ${ }^{\star}$ forest type are shown as differences from the values recorded in the natural forests.

\begin{tabular}{|c|c|c|c|c|}
\hline & \multicolumn{2}{|c|}{ Butterfly richness } & \multicolumn{2}{|c|}{ Butterfly abundance } \\
\hline & Coeff. (SE) & $P$ & Coeff. (SE) & $P$ \\
\hline \multicolumn{5}{|l|}{ Explanatory variables } \\
\hline Canopy stem density & - & & - & \\
\hline Shrub stem density & - & & - & \\
\hline Canopy DBH & - & & - & \\
\hline$\%$ deciduous trees & - & & $0.335(0.114)$ & 0.013 \\
\hline Total host plant richness & $0.350(0.179)$ & 0.051 & - & \\
\hline Canopy openness & $1.824(0.838)$ & 0.030 & $3.599(0.585)$ & $<0.001$ \\
\hline Forest type (plantation) & $-0.237(0.458)$ & 0.605 & $-1.064(0.269)$ & 0.002 \\
\hline Openness ${ }^{*}$ forest type & $-1.589(0.815)$ & 0.051 & $-3.043(0.593)$ & $<0.001$ \\
\hline Distance to forest edge & - & & - & \\
\hline Degree of freedom & 4,11 & & 4,11 & \\
\hline Pseudo $\mathrm{R}^{2 *}$ & 0.787 & & 0.895 & \\
\hline Model & Poisson GLM & & Quasi-GLM & \\
\hline$\varphi$ & 1.016 & & 2.049 & \\
\hline
\end{tabular}

* Pseudo $\mathrm{R}^{2}$ : (null deviance-residual deviance)/null deviance.

freedom) is larger than 1.5 , over dispersion needs to be corrected (Zuur et al., 2009). Therefore, in such cases, standard errors were corrected using a quasi-GLM model where the variance was given by $\varphi \times \mu$ where $\mu$ is the mean and we continued to delete variables with $P s>0.1$. We set $\alpha=0.1$ instead of 0.05 because variables with $P<0.1$ were always included in the model during the AIC-based model selection process. Meanwhile, for the herbaceous plant feeding butterflies, no individuals were recorded at six of the eight natural forest sites and only one individual at one natural forest site. As a result, the remaining one natural forest site was an outlier. Therefore, for the herbaceous plant feeding butterflies, a Poisson GLM was used only for the plantation sites. In the GLMs, the number of explanatory variables was seven (i.e., forest type and the interaction between openness and forest type were excluded), whereas the number of sites was eight, which indicated that it is impossible to include all seven variables simultaneously (the maximum is six variables). Consequently, we combined seven of the six variables and carried out a backward model selection for each combination. Then, we selected the models with the lowest AIC from among all the combinations as being the most parsimonious and checked the dispersion parameters of these models. None of these models were over dispersed.
For all GLMs, the explanatory variables were standardized in order to evaluate the relative contribution of each variable.

The relationship between the number of flower-feeding individuals and flower plant richness was tested using Spearman's rank correlation.

All statistical analyses were done using R 3.1.3 (R Core Team, 2015).

\section{RESULTS}

Ninety-two species of flowering plants were recorded as potential sources of nectar; however, only five of these species were observed to be fed on by butterflies. Of the 92 species, 4 species were non native and only recorded in plantations. In total, 187 individuals belonging to 33 species of butterfly were recorded during the entire survey. Species richness ranged from 0 to 14 , and butterfly counts ranged from 0 to 47 per site. A total of 59 individuals belonging to 15 species were tree feeders, whereas 117 individuals belonging to 12 species were herbaceous plant feeders. The majority of individuals were recorded resting (105 individuals, $56 \%$ ), followed by flying (62 individuals, $33 \%)$. Only 14 individuals $(7.5 \%)$ were recorded feeding on flowers. The number of flower-feeding individuals was positively correlated with flower plant richness (Spearman's rho $=0.529, n=16, P=0.034)$.

Flower plant richness and flower abundance were most strongly associated with canopy openness and the interaction between canopy openness and forest type (Table 1). Both of these flower variables increased with increasing canopy openness; however, the slopes of the regression lines were steeper for natural forests than for plantations (Fig. 1a). Flower abundance was also positively associated with the percentage of deciduous trees (Table 1). Herbaceous host plant richness increased with increasing canopy openness, and with steeper regression slopes for natural forests than for plantations (Fig. 1b, Table 2). By contrast, tree host plant richness was only significantly correlated with tree species richness (Fig. 1c, Table 2). Total host plant richness looked similar to the average of the tree and herbaceous host plant richness, with positive associations

Table 4. Results of the GLMs with a Poisson error distribution used to analyse the species richness and abundances of tree feeders and herbaceous plant feeders. The explanatory variables are standardized. The coefficients and SE of the environmental variables for the most parsimonious models are shown. The coefficients for forest type and the interaction between canopy openness ${ }^{\star}$ forest type are shown as differences from the values recorded in the natural forests.

\begin{tabular}{|c|c|c|c|c|c|c|c|c|}
\hline & \multicolumn{4}{|c|}{ Tree feeders } & \multicolumn{4}{|c|}{ Herbaceous plant feeders } \\
\hline & \multicolumn{2}{|l|}{ Richness } & \multicolumn{2}{|c|}{ Abundance } & \multicolumn{2}{|c|}{ Richness } & \multicolumn{2}{|c|}{ Abundance } \\
\hline & Coeff. (SE) & $P$ & Coeff. (SE) & $P$ & Coeff. (SE) & $P$ & Coeff. (SE) & $P$ \\
\hline \multicolumn{9}{|l|}{ Explanatory variables } \\
\hline Canopy stem density & - & & - & & - & & - & \\
\hline Shrub stem density & - & & - & & - & & - & \\
\hline Canopy DBH & - & & - & & - & & $1.478(0.729)$ & 0.043 \\
\hline$\%$ deciduous trees & - & & - & & $0.753(0.309)$ & 0.015 & 2.082 (0.861) & 0.016 \\
\hline Host plant richness & - & & - & & - & & $-1.261(0.683)$ & 0.065 \\
\hline Canopy openness & $2.086(0.773)$ & 0.007 & $2.415(0.713)$ & 0.005 & $0.707(0.246)$ & 0.004 & $3.489(1.270)$ & 0.006 \\
\hline Forest type (plantation) & $-1.423(0.491)$ & 0.004 & $-1.582(0.455)$ & 0.005 & not tested & & not tested & \\
\hline Openness*forest type & $-1.747(0.802)$ & 0.029 & $-2.070(0.742)$ & 0.016 & not tested & & not tested & \\
\hline Distance to forest edge & - & & - & & $0.547(0.326)$ & 0.093 & $1.066(0.537)$ & 0.047 \\
\hline Degree of freedom & 3,12 & & 3,12 & & 3,4 & & 5,2 & \\
\hline Pseudo $\mathrm{R}^{2 *}$ & 0.425 & & 0.483 & & 0.873 & & 0.995 & \\
\hline Model & Poisson GLM & & Quasi-GLM & & Poisson GLM & & Poisson GLM & \\
\hline$\varphi$ & 1.082 & & 2.144 & & 0.481 & & 0.225 & \\
\hline
\end{tabular}

* Pseudo $\mathrm{R}^{2}$ : (null deviance-residual deviance)/null deviance. 


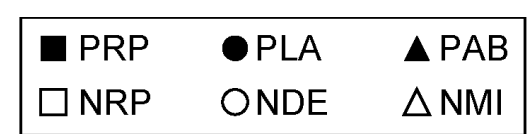

(a)
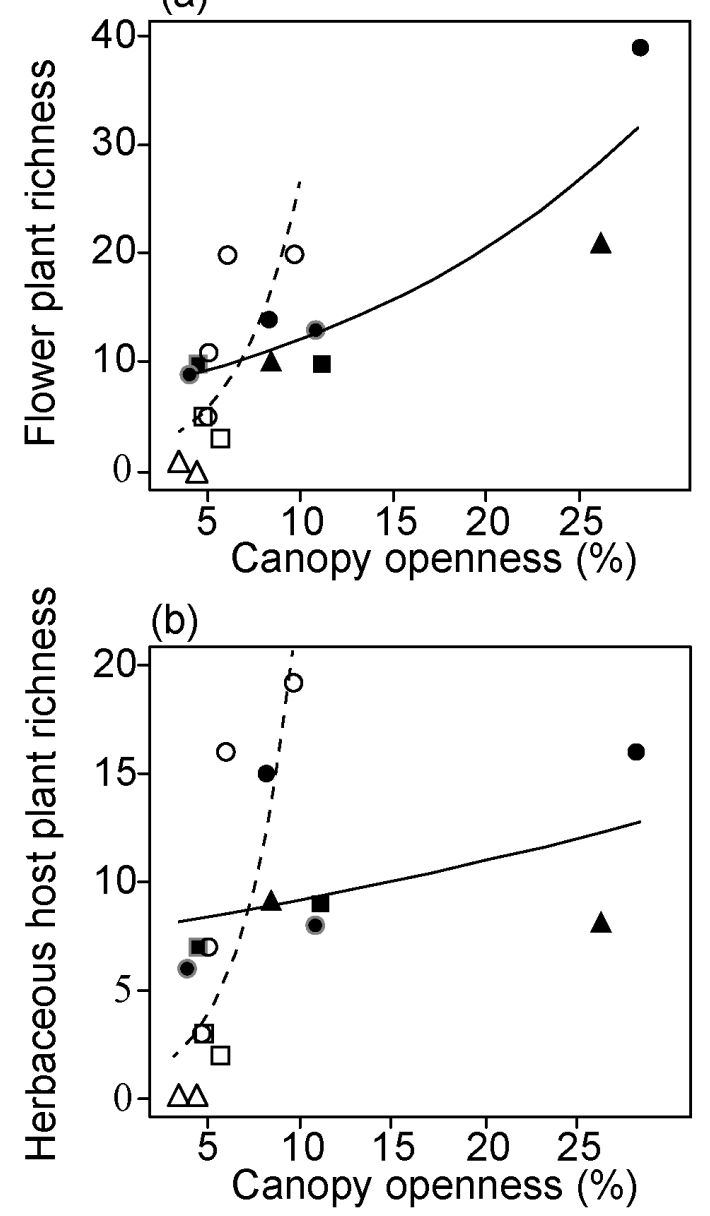

(c)

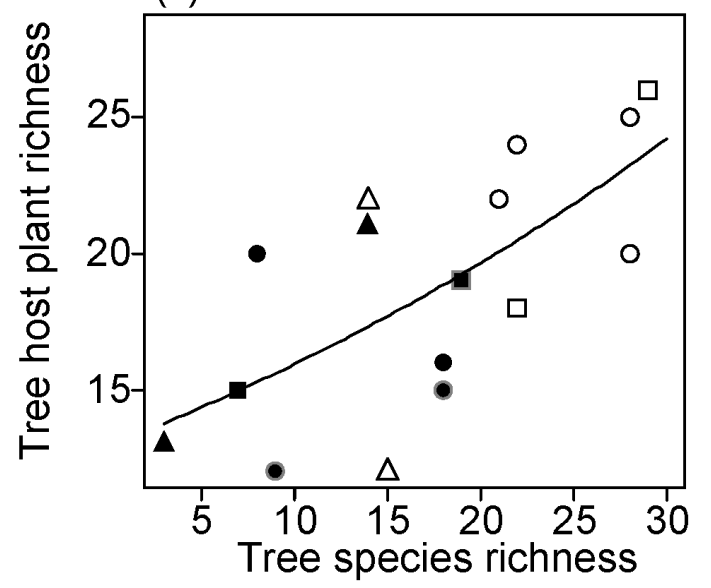

Fig. 1. The relationships between (a) canopy openness and flower plant richness, (b) canopy openness and herbaceous host plant richness, and (c) tree species richness and tree host plant richness. PRP - red pine plantation, PLA - larch plantation, PAB silver fir plantation, NRP - natural red pine forest, NMI - natural mixed forest, NDE - natural broadleaved deciduous forest. When significant differences were detected between forest types, natural forests (empty symbols) and plantation forests (solid symbols) are shown with dashed and solid lines, respectively. The three sites where transects were not established along the trails are shown with grey borders. with tree species richness and canopy openness. However, the interaction was not significant for total host plant richness. Total and herbaceous host plant richness were also positively correlated with canopy DBH even though the correlations were insignificant for total host plants (Table 2).

Total and tree-feeding butterfly species richness and abundances were also most strongly associated with canopy openness and the interaction between canopy openness and forest type, with steeper positive slopes recorded in natural forests than in plantations, although the significance of the interaction was marginal for total butterfly richness (Fig 2a-d, Tables 3-4). Total host plant richness and the percentage of deciduous trees were slightly positively associated with total butterfly richness and abundance, respectively (Table 3). For herbaceous plant feeding butterfly richness and abundance, canopy openness was the most important positively associated factor, followed by the percentage of deciduous trees (Fig. 2e, f, Table 4). In plantations, the herbaceous plant feeders showed a stronger association with increasing canopy openness than tree feeders (Fig. 2c-f). Because all explanatory variables were standardized, we can evaluate the importance of the variables by comparing the coefficients of each variable (higher absolute values indicate greater associations with butterfly resources, butterfly richness and abundance). Overall, forest structural variables (i.e., stem density and canopy DBH), host plant richness and distance to forest edge were little associated with butterfly resources and butterfly richness and abundances, whereas canopy openness was almost always the most strongly associated, with the interaction between canopy openness and forest type also important in many cases (Tables 1-4).

\section{DISCUSSION}

The results of the present study generally support our hypotheses, and indicate strong associations with canopy openness, forest type (plantations or natural forests) and their great importance in the interaction between both plants and butterflies. The relationships between the percentage of deciduous trees and flower abundance, total butterfly abundance and herbaceous plant feeding butterfly richness and abundance may also indicate the positive effects of improving light conditions in forests. The greater butterfly richness and abundance recorded at more sunny sites may be due to an increase in detectability associated with increasing canopy openness. However, such an effect is likely to have been negligible because we beat the branches of shrubs and in the sub canopy during the peak butterfly season (June-August) in order to detect butterflies and the visibility at even some sites with closed canopies was excellent because of the scarcity of understory vegetation. Red Listed species of butterflies were not recorded during the present study and very few species (only four individuals of Parnara guttata and one of Fabriciana addipe) that prefer open areas were recorded. Therefore, it was mainly forest and edge species that were recorded along sunny forest trails. 


\begin{tabular}{|lll|}
\hline PRP & OPLA & $\triangle \mathrm{PAB}$ \\
$\square \mathrm{NRP}$ & ONDE & $\triangle \mathrm{NMI}$ \\
\hline
\end{tabular}

(a) All butterflies

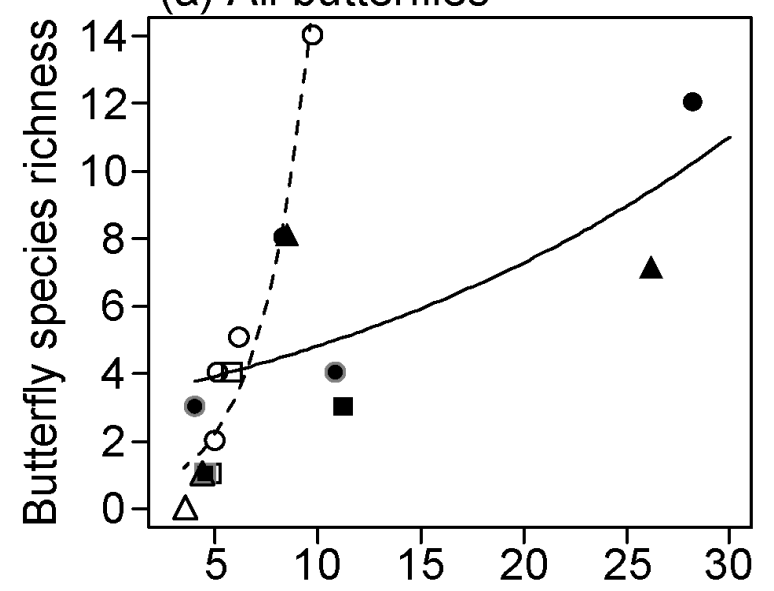

(c) Tree feeders

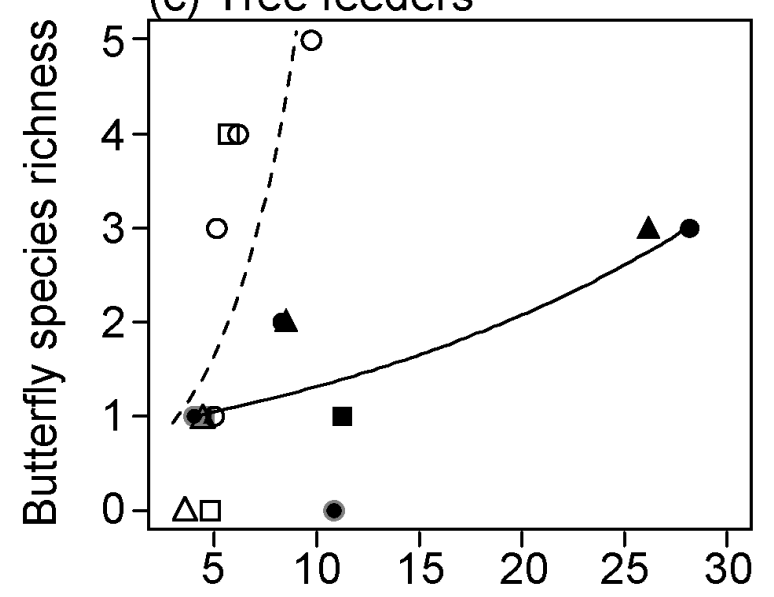

(e) Herb feeders

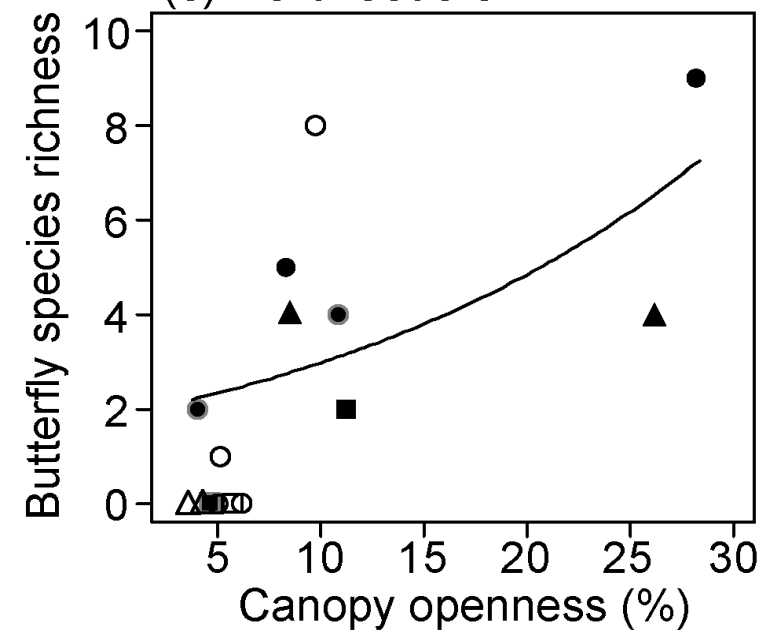

(b) All butterflies

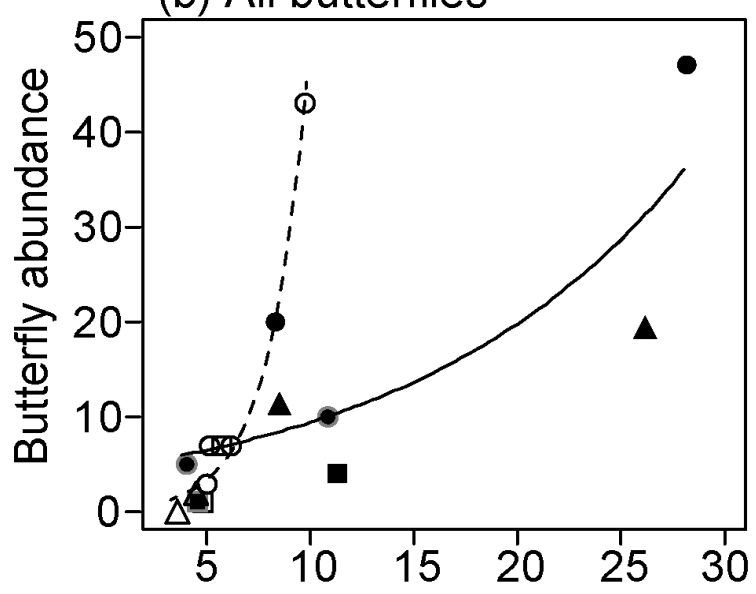

(d) Tree feeders

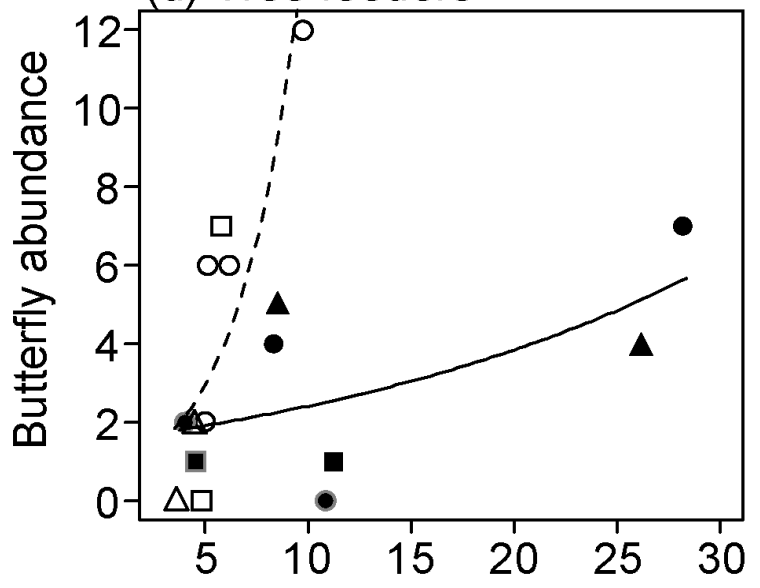

(f) Herb feeders

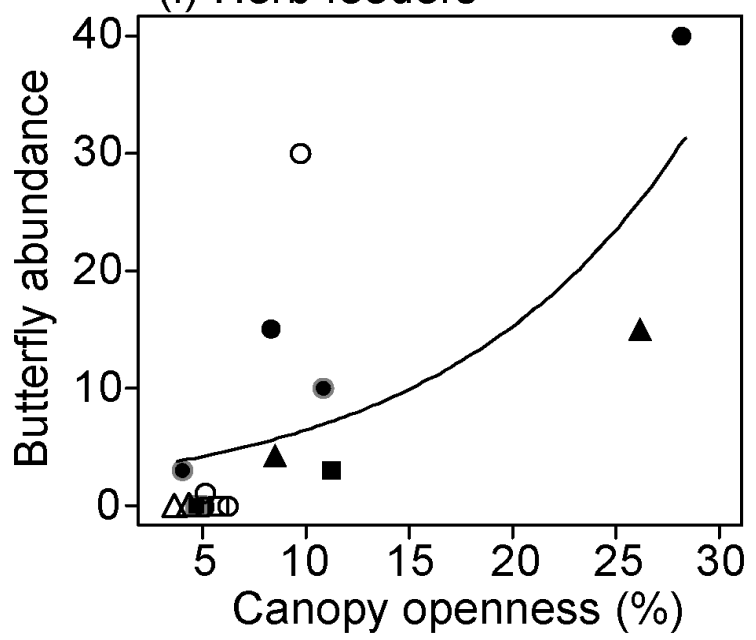

Fig. 2. The relationships between canopy openness and (a) the total butterfly species richness, (b) the total butterfly abundance, (c) species richness of tree feeders, (d) abundance of tree feeders, (e) species richness of herbaceous plant feeders, (f) abundance of herbaceous plant feeders. PRP - red pine plantation, PLA - larch plantation, PAB - silver fir plantation, NRP - natural red pine forest, NMI - natural mixed forest, NDE - natural broadleaved deciduous forest. When significant differences were detected between forest types, natural forests (empty symbols) and plantation forests (solid symbols) are shown with dashed and solid lines, respectively. The three sites where transects were not established along the trails are shown with grey borders. 
In the present study, the total number of individuals recorded was low (only 187 individuals). This could be due to bad weather or the site characteristics specific to the region. We simultaneously surveyed butterfly assemblages in three clear cut areas and four grasslands sites using the same research protocol (same transect length of $200 \mathrm{~m}$ over the same interval of time during the same period). At these 7 sites, 454 butterflies were recorded (on average, the butterfly densities at these open sites were approximately 5.5 times greater than those recorded at the forest sites). In the region studied, many forested areas are composed of coniferous plantations, and even natural forests are sometimes dominated by coniferous trees, which are not palatable to butterflies. In addition, bamboo grasses are quite rare in this region. Therefore, butterflies that feed on bamboo grasses were a minor component of those recorded in the present study (only five individuals), although they are often dominant in forested areas in Japan (Nishinaka \& Ishii, 2006; Ohwaki et al., 2007). Butterfly surveys were carried out when the weather conditions were appropriate for monitoring butterflies as outlined in the "Butterfly counts" section; therefore, the low butterfly total abundance recorded in the present study is much more likely to be due site characteristics specific to the region than bad weather.

We discovered that plant responses to canopy openness differed in plantations and natural forests. Because the majority of the flowering plants were native species, the extent of the canopy openings recorded in the present study did not favour colonization by non native plants. In shady conditions the flower plant richness and herbaceous host plant richness were higher in plantations than in natural forests; however, this relationship was reversed if canopy openness exceeded 7-8\% (Fig. 1a, b). Management by thinning removes non-target species of trees as well as unhealthy planted trees, which results in lower tree stem densities in plantations (Fig. S2). In shaded conditions in plantations where there are few stems per unit area some herbaceous plants are able to grow, whereas where there are many tree stems per unit area, as in natural forests, there is less herbaceous vegetation and fewer nectariferous flowers and herbaceous host plants (Paillet et al., 2010). However, the initial preparation of a site for afforestation may damage the original herbaceous flora and the resulting undeveloped vertical forest structure with few species of trees does not favour the area being colonized by animal and bird seed dispersers from the plantations (Hartley, 2002; Nagaike, 2002). Therefore, these features might result in a slower recovery of nectariferous flowers and host plants in plantations than in natural forests where light conditions are more favourable. In addition, as was expected, tree host plant richness was related solely to tree species richness. Because tree species richness was lower in plantations than in natural forests (Fig. 1c, Fig. S2), monoculture and management by thinning in plantations have attributed more to the reduction in tree richness than anything else.

Richness and abundance of all butterflies, tree-feeding and herbaceous plant feeding butterflies are most strongly associated with canopy openness, forest type (plantations or natural forests), or the interaction between the two (Fig. 2a-d, Tables 3-4). Because many previous studies report a positive association between nectariferous flowers and host plant richness, and the abundance of butterflies (Clausen et al., 2001; Pywell et al., 2004; van Halder et al., 2011; Soga et al., 2015), the greater increase in butterfly richness and abundance with increasing canopy openness in natural forests than in plantations might be explained, at least partially, by the associated greater increase in nectariferous flowers and host plants recorded in natural forests. Although we could not include flower plant richness and abundance in the GLMs of butterflies due to the high VIF values and host plant richness was usually insignificant, we discovered a positive association between flower plant richness and the number of butterflies that were observed feeding on flowers. This indicates that the positive effects of canopy openness on butterflies could be partially explained by the increase in flower plant richness. However, the low percentage of individuals feeding on flowers $(7.5 \%)$ and the high percentage of individuals resting (56\%) indicates that only improving light conditions can attract butterflies. Butterflies require not only sources of nectar and larval host plants, but also roosting and mating sites (Dennis et al., 2003). Open spaces in forests, such as forest gaps are often defended as territories and used for mating and thermoregulation by forest butterflies (Ide, 2001; Dennis, 2010). Thus, increased canopy openness not only leads to an increase in the numbers of nectariferous flowers and nectar-feeding butterflies but also attracts butterflies that use them as territory markers and for thermoregulation. In addition, although the influences of landscape structure on butterflies are well known (Weibull et al., 2000; Bergman et al., 2004; Rossi \& van Halder, 2010), the effects of the distance to the edge of the forest are mostly negligible. There may be several reasons for the lack of landscape effects. First, if the species of butterflies are mobile enough to disperse from source populations to more suitable sites within forests in a landscape, which is likely to be the case for some species, any effect of the distance to the edge of the forest is unlikely to be detected. Some previous studies have shown that local factors appear to be more significant than landscape factors (Bergman et al., 2008; van Halder et al., 2008; Pöyry et al., 2009; Berg et al., 2011). Second, because the influence of landscape factors was not included in the present study (the selected forests were at least $>3$ ha and were separated from other types of forest / forest edges by at least $20 \mathrm{~m}$ ), this might have prevented the detection of the effect of landscape factors. Third, the distance to the edge of the forest might not be a suitable measure of sources of butterflies and thus landscape effects. Other landscape variables, such as distance to the nearest deciduous forest, might better explain butterfly richness and abundance. However, some deciduous forests are butterfly-poor (e.g., NDE 1 and NDE 3), which indicates that local factors are more important than landscape factors in the area studied.

The results of the present study indicate a clear difference in the response to canopy openness of tree and herbaceous 
plant feeders. When canopy openness increases from $5 \%$ to $28 \%$ in the plantations, tree feeders, on average, increase from one to three species and from two to six individuals, whereas herbaceous plant feeders increase from on average two to seven species and from four to approximately thirty individuals (Fig. 2c-f). Therefore, although it is difficult to increase the number of tree feeders by increasing canopy openness once natural forests are converted into plantations, herbaceous plant feeders, including fritillaries, satyrids and skippers feeding on violas, grasses, and sedges benefit greatly from increased canopy openness in plantations and reflect the increases recorded in both nectariferous flowers and herbaceous host plants.

The present study leaves several issues unresolved. First, we could not test some forest structural and compositional variables because many explanatory variables are correlated with each other. To evaluate the importance of these variables, forests of the same type and same age, but which differ in the density and composition of sub canopy, shrub and herbaceous layers, should be investigated. Second, although we adopted the dichotomy "plantation or natural forest," both plantations and natural forests contain several different types of forests. In plantations, larch is deciduous, whereas the silver fir and red pine are evergreen. The difference deciduous or evergreen affects a wide range of organisms, including plants, birds and insects (Smith et al., 2008; Bremer\& Farley, 2010; Yamaura et al., 2012). Butterfly richness and abundances in red pine plantations were always lower than expected (below the regression lines, Fig. 2). Because there were several types of plantations in the area studied, the effects of trees planted need to be examined in greater detail in the future. Third, within the three sites, the transects were established in the interior of plantations, not along trails. Because butterfly richness and abundances were usually lower than expected at the three sites (Fig. 2), it is possible that this difference in the location of the transects may have affected our results. One possible explanation of this phenomena is that the light conditions in the interior of forests is relatively uniform along the transects; whereas, the light conditions along the trails were much brighter, and were, therefore, in sharp contrast to the surroundings in the shady forest interior. If canopy openness is at a similar level, butterflies may be more attracted to the brighter forest trails that contrast strongly with the light conditions in shady forest interiors. Finally, herbaceous plant feeding butterflies were not recorded at the majority of the natural forest sites. Canopy openness at these sites was lower than at the six plantation sites (Figs 1-2, Table S1). It is likely that canopy openness in these shady natural forests were lower than the threshold value for observing butterflies. Therefore, to examine the effects of canopy openness in natural forests, it is necessary to sample natural forests with a large variation in canopy openness, such as in plantations.

The importance of canopy openness recorded in the present study makes it important to consider open forest management in other temperate regions. Vera (2000) proposes a much debated theory that prehistoric European temperate forests, particularly oak forests, were rather open, which is contrary to the view that closed forests were the natural state. Until the recent past, temperate forests in both Europe and East Asia were kept open as coppice or woodpasture for millennia (Kato, 2001; Fartmann et al., 2013). If temperate forests were originally open, many species would have evolved in open forests and open forests would support a high biodiversity and many forest specialists. Several studies from Europe have revealed that open forest management, such as coppicing, increases biodiversity and even forest specialists of vascular plants, butterflies, saproxylic beetles, carabid beetles, arachnids and reptiles (Benes et al., 2006; Spitzer et al., 2008; Fartmann et al., 2013; Sebek et al., 2015). In temperate Japan, clearing coppice woods increases the abundance of not only butterflies that prefer open spaces, but also forest butterflies (Inoue, 2003). In addition, sunny forest stands, rides, tracks and glades in woodlands and plantations harbour a higher richness of herbaceous plants (Sparks et al., 1993; Buckley et al., 1997; Smith et al., 2007), butterflies (Warren, 1985; Greatorex-Davies, 1993; van Halder et al., 2011) and cerambycid and chrysomelid beetles (Ohsawa, 2004; Ohsawa \& Nagaike, 2006) than shady stands, rides, tracks and glades. Large wind throw gaps also contribute to enhancing insect diversity in forest ecosystems (Bouget \& Duelli, 2004). Therefore, although we should note that widening trails can sometimes lead to an increase in the numbers of non native plants (Buckley et al., 1997), creating sunlit spaces seem to be essential for enhancing biodiversity in temperate forests. Because stand-level plantation management is labour intensive (Cumming \& Reid, 2008), labour and cost saving trail management options need to be explored in greater detail as a means of creating open areas and increase biodiversity in plantations in temperate regions.

ACKNOWLEDGEMENTS. We thank the local land owners and land managers for allowing us to carry out our research, and two anonymous reviewers for their constructive comments. This work was partially supported by JSPS KAKENHI Grant Number $16 \mathrm{~K} 07800$. The authors declare that they have no conflicts of interest.

\section{REFERENCES}

Barlow J., Gardner T.A., Araujo I.S., Ávila-Pires T.C., Bonaldo A.B., Costa J.E., Esposito M.C., Ferreira L.V., Hawes J. Hernandez M.I.M. ET AL. 2007a: Quantifying the biodiversity value of tropical primary, secondary, and plantation forests. Proc. Natl. Acad. Sci. U.S.A. 104: 18555-18560.

Barlow J., Overal W.L., Araujo I.S., Gardner T.A. \& Peres C.A. 2007b: The value of primary, secondary and plantation forests for fruit-feeding butterflies in the Brazilian Amazon. J. Appl. Ecol. 44: 1001-1012.

Barlow J., Araujo I.S., Overal W.L., Gardner T.A., Mendes F. DA S., LAKe I.R. \& Peres C.A. 2008: Diversity and composition of fruit-feeding butterflies in tropical Eucalyptus plantations. - Biodiv. Conserv. 17: 1089-1104.

Benes J., Cizek O., Dovala J. \& Konvicka M. 2006: Intensive game keeping, coppicing and butterflies: The story of Milovicky Wood, Czech Republic. - For. Ecol. Manage. 237: 353-365. 
Berg Å., Ahrné K., Öckinger E., Svensson R. \& Söderström B. 2011: Butterfly distribution and abundance is affected by variation in the Swedish forest-farmland landscape. - Biol. Conserv. 144: 2819-2831.

Bergman K., Askling J., Ekberg O., Ignell H., Wahlman H. \& Milberg P. 2004: Landscape effects on butterfly assemblages in an agricultural region. - Ecography 27: 619-628.

Bergman K.-O., Ask L., Askling J., Ignell H., Wahlman H. \& MILBERG P. 2008: Importance of boreal grasslands in Sweden for butterfly diversity and effects of local and landscape habitat factors. - Biodivers. Conserv. 17: 139-153.

Bouget C. \& Duelli P. 2004: The effects of windthrow on forest insect communities: a literature review. - Biol. Conserv. 118: 281-299.

Bremer L.L. \& FARLEy K.A. 2010: Does plantation forestry restore biodiversity or create green deserts? A synthesis of the effects of land-use transitions on plant species richness. - Biodiv. Conserv. 19: 3893-3915.

Brockerhoff E.G., Jactel H., Parrotta J.A., Quine C.P. \& Sayer J. 2008: Plantation forests and biodiversity: oxymoron or opportunity? - Biodiv. Conserv. 17: 925-951.

Buckley G.P., Howell R., Watt T.A., Ferris-Kaan R. \& ANDERSON M.A. 1997: Vegetation succession following ride edge management in lowland plantations and woods. 1. The influence of site factors and management practices. - Biol. Conserv. 82: 289-304.

Bus de Warnaffe G. Du \& Deconchat M. 2008: Impact of four silvicultural systems on birds in the Belgian Ardenne: implications for biodiversity in plantation forests. - Biodiv. Conserv. 17: 1041-1055.

Clausen H.D., Holbeck H.B. \& Reddersen J. 2001: Factors influencing abundance of butterflies and burnet moths in the uncultivated habitats of an organic farm in Denmark. - Biol. Conserv. 98: 167-178.

Cummings J. \& Reid N. 2008: Stand-level management of plantations to improve biodiversity values. - Biodiv. Conserv. 17: $1187-1211$

DenNIS R.L.H. 2004: Butterfly habitats, broad-scale biotope affiliations, and structural exploitation of vegetation at finer scales: the matrix revisited. - Ecol. Entomol. 29: 744-752.

DenNis R.L.H. 2010: A Resource-Based Habitat View for Conservation: Butterflies in the British Landscape. Wiley-Blackwell, Chichester, 406 pp.

Dennis R.L.H., Shreeve T.G. \& Van Dyck H. 2003: Towards a functional resource-based concept for habitat: a butterfly biology viewpoint. - Oikos 102: 417-426.

Dumbrell A.J. \& HiLl J.K. 2005: Impacts of selective logging on canopy and ground assemblages of tropical forest butterflies: Implications for sampling. - Biol. Conserv. 125: 123-131.

Fartmann T., Müller C. \& Poniatowski D. 2013: Effects of coppicing on butterfly communities of woodlands. - Biol. Conserv. 159: 396-404.

Forestry Agency Japan 2016: Statistics on Forest and Forestry 2016. Ministry of Agriculture, Forestry and Fisheries, Tokyo [in Japanese].

Fukamachi K., OKu H. \& NakashizuKa T. 2001: The change of a satoyama landscape and its causality in Kamiseya, Kyoto Prefecture, Japan between 1970 and 1995. — Landsc. Ecol. 16: 703-717.

Fukuda H., Hama E., Kuzuya T., Takahashi A., Takahashi M., Tanaka B., Tanaka H., Wakabayashi M. \& Watanabe Y. 1982 The Life Histories of Butterflies in Japan. Vols I, II, III, and IV. Hoikusha, Osaka [in Japanese].

Greatorex-Davies J.N., Sparks T.H., Hall M.L. \& Marss R.H. 1993: The influence of shade on butterflies in rides of conifer- ised lowland woods in Southern England and implications for conservation management. - Biol. Conserv. 63: 31-41.

HAMER K.C. \& Hill J.K. 2000: Scale-dependent effects of habitat disturbance on species richness in tropical forests. - Conserv. Biol. 14: 1435-1440.

Hamer K.C., Hill J.K., Lace L.A. \& Langan A.M. 1997: Ecological and biogeographical effects of forest disturbance on tropical butterflies of Sumba, Indonesia. - J. Biogeogr. 24: 67-75.

Hamer K.C., Hill J.K., Benedick S., Mustaffa N., Sherratt T.N., Maryati M. \& CheY V.K. 2003: Ecology of butterflies in natural and selectively logged forests of northern Borneo: The importance of habitat heterogeneity. - J. Appl. Ecol. 40: $150-162$.

Hamer K.C., Hill J.K., Mustaffa N., Benedick S., Sherratt T.N., Chey V.K. \& Maryati M. 2005: Temporal variation in abundance and diversity of butterflies in Bornean rain forests: Opposite impacts of logging recorded in different seasons. $-J$ Trop. Ecol. 21: 417-425.

HARTLEY M.J. 2002: Rationale and methods for conserving biodiversity in plantation forests. - For. Ecol. Manage. 155: 81-95.

Hill J.K., Hamer K.C., Lace L.A. \& Banham W.M.T. 1995: Effects of selective logging on tropical forest butterflies on Buru, Indonesia. - J. Appl. Ecol. 32: 754-760.

IDE J.-Y. 2001: Microhabitat differences in two Lethe butterflies (Lepidoptera: Nymphalidae) concerning thermoregulation. Entomol. Sci. 4: 279-285.

INOUE T. 2003: Chronosequential change in a butterfly community after clear-cutting of deciduous forests in a cool temperate region of central Japan. - Entomol. Sci. 6: 151-163.

Kато M. 2001: 'Satoyama' and biodiversity conservation: 'Satoyama' as important insect habitats. - Global Environ. Res. 5: $135-149$.

Kim S.-S. \& Seo Y. 2012: Life Histories of Korean Butterflies. Sagyejel, Paju, 538 pp. [in Korean]

Kitahara M. 2004: Butterfly community composition and conservation in and around a primary woodland of Mount Fuji, central Japan. - Biodiv. Conserv. 13: 917-942.

Kuussaari M., Heliölä J., Luoto M. \& Pöyry J. 2007: Determinants of local species richness of diurnal Lepidoptera in boreal agricultural landscapes. - Agric. Ecosyst. Environ. 122: 366-376.

LindenMaYer D.B. \& HobBS R.J. 2004: Fauna conservation in Australian plantation forests - a review. - Biol. Conserv. 119: 151-168.

Maeto K., Sato S. \& Miyata H. 2002: Species diversity of longicorn beetles in humid warm-temperate forests: the impact of forest management practices on old-growth forest species in southwestern Japan. - Biodiv. Conserv. 11: 1919-1937.

Magura T., Tóthmérész B. \& Bordán Z. 2000: Effects of nature management practice on carabid assemblages (Coleoptera: Carabidae) in a non-native plantation. - Biol. Conserv. 93: 95-102.

Martikainen P., Sittonen J., Punttila P., Kaila L. \& Rauh J. 2000: Species richness of Coleoptera in mature managed and old-growth boreal forests in southern Finland. - Biol. Conserv. 94: 199-209.

NAGAIKE T. 2000: A review of ecological studies on plant species diversity in plantation ecosystems. - J. Jap. For. Soc. 82: 407-416 [in Japanese, English abstr.].

NAGAIKE T. 2002: Differences in plant species diversity between conifer (Larix kaempferi) plantations and broad-leaved (Quercus crispula) secondary forests in central Japan. - For. Ecol. Manage. 168: 111-123.

NishinAKA Y. \& IsHII M. 2006: Effects of experimental mowing on species diversity and assemblage structure of butterflies 
in a coppice on Mt Mikusa, northern Osaka, central Japan. Trans. Lepid. Soc. Jap. 57: 202-216.

OHSAWA M. 2004: Species richness of Cerambycidae in larch plantations and natural broad-leaved forests of the central mountainous region of Japan. - For. Ecol. Manage. 189: 375-385.

OhsaWa M. \& NagaiKe T. 2006: Influence of forest types and effects of forestry activities on species richness and composition of Chrysomelidae in the central mountainous region of Japan. - Biodiv. Conserv. 15: 1179-1191.

Ohwaki A., Tanabe S.-I. \& Nakamura K. 2007: Butterfly assemblages in a traditional agricultural landscape: importance of secondary forests for conserving diversity, life history specialists and endemics. - Biodiv. Conserv. 16: 1521-1539.

Ohwaki A., Hayami S., Kitahara M. \& Yasuda T. in press: The role of linear mown firebreaks in conserving butterfly diversity: effects of adjacent vegetation and management. - Entomol. Sci. DOI: 10.1111/ens. 12289

Paillet Y., Bergès L., Huältén J., Ódor P., Avon C., BernhardtRömermann M., Bijlsma R., De Bruyn L., Fuhr M., Grandin U. ET AL. 2010: Biodiversity differences between managed and unmanaged forests: Meta-analysis of species richness in Europe. - Conserv. Biol. 24: 101-112.

Payn T., Carnus J.-M., Freer-Smith P., Kimberley M., Kollert W., Liu S., Orazio C., Rodriguez L., Silva L.N. \& Wingfield M.J. 2015: Changes in planted forests and future global implications. - For. Ecol. Manage. 352: 57-67.

Pollard E. \& Yates T.J. 1993: Monitoring Butterflies for Ecology and Conservation. Chapman \& Hall, London, 274 pp

Pöyry J., Paukkunen J., Heliölä J. \& KuUSSAari M. 2009: Relative contributions of local and regional factors to species richness and total density of butterflies and moths in semi-natural grasslands. - Oecologia 160: 577-587.

Pywell R.F., Warman E.A., Sparks T.H., Greatorex-Davies J.N., Walker K.J., Meek W.R., Carvell C., Petit S. \& Firbank L.G. 2004: Assessing habitat quality for butterflies on intensively managed arable farmland. - Biol. Conserv. 118: 313-325.

R Core Team 2015: R: A Language and Environment for Statistical Computing. R Foundation for Statistical Computing. Vienna. URL: http://www.R-project.org/ (last accessed 3 Aug. 2017).

Robertson P.A., Clarke S.A. \& Warren M.S. 1995: Woodland management and butterfly diversity. In Pullin A.S. (ed.): Ecology and Conservation of Butterflies. Chapman \& Hall, London, pp. 113-122.

ROSSI J.-P. \& VAN HALDER I. 2010: Towards indicators of butterfly biodiversity based on a multiscale landscape description. Ecol. Indic. 10: 452-458.

Saito M.U., Jinbo U., Yago M., Kurashima O. \& Ito M. 2016: Larval host records of butterflies in Japan. - Ecol. Res. 31: 491-491.

Sebek P., Bace R., Bartos M., Benes J., Chlumska Z., Dolezal J., Dvorsky M., Kovar J., Machac O., Mikatova B. et al. 2015: Does a minimal intervention approach threaten the biodiversity of protected areas? A multi-taxa short-term response to intervention in temperate oak-dominated forests. - For. Ecol. Manage. 358: 80-89.

Smith G.F., Gittings T., Wilson M., French L., Oxbrough A., O’Donoghue S., O’Halloran J., Kelly D.L., Mitchell F.J.G., KELLY T. ET AL. 2008: Identifying practical indicators of biodiversity for stand-level management of plantation forests. Biodiv. Conserv. 17: 991-1015.

Smith G.F., Iremonger S., Kelly D.L., O’Donoghue S. \& MitchELL F.J.G. 2007: Enhancing vegetation diversity in glades, rides and roads in plantation forests. - Biol. Conserv. 136: 283-294.
Soga M., Kawahara T., Fukuyama K., Sayama K., Kato T., Shimomura M., Ito T., Yoshida T. \& OzaKi K. 2015: Landscape versus local factors shaping butterfly communities in fragmented landscapes: Does host plant diversity matter? - J. Insect Conserv. 19: 781-790.

Sparks T.H., Greatorex-Davies J.N., Mountford J.O., Hall M.L. \& Marrs R.H. 1996: The effects of shade on the plant communities of rides in plantation woodland and implications for butterfly conservation. - For. Ecol. Manage. 80: 197-207.

Sitzzer L., Konvicka M., Benes J., Tropek R., Tuf I.H. \& Tufova J. 2008: Does closure of traditionally managed open woodlands threaten epigeic invertebrates? Effects of coppicing and high deer densities. - Biol. Conserv. 141: 827-837.

Taki H., Inoue T., Tanaka H., Makihara H., Sueyoshi M., Isono M. \& OKАВE K. 2010: Responses of community structure, diversity, and abundance of understory plants and insect assemblages to thinning in plantations. - For. Ecol. Manage. 259: 607-613.

van Halder I., Barbaro L., Corcket E. \& Jactel H. 2008: Importance of semi-natural habitats for the conservation of butterfly communities in landscapes dominated by pine plantations. -Biodiv. Conserv. 17: 1149-1169.

van Halder I., Barbaro L. \& Jactel H. 2011: Conserving butterflies in fragmented plantation forests: are edge and interior habitats equally important? - J. Insect Conserv. 15: 591-601.

Vera F.W.M. 2000: Grazing Ecology and Forest History. CABI Publishing, Wallingford, $506 \mathrm{pp}$.

Verdasca M.J., Leitao A.S., Santana J., Porto M., Dias S. \& BEJA P. 2012: Forest fuel management as a conservation tool for early successional species under agricultural abandonment: The case of Mediterranean butterflies. - Biol. Conserv. 146: $14-23$.

WARREN M.S. 1985: The influence of shade on butterfly numbers in woodland rides, with special reference to the wood white Leptidea sinapis. - Biol. Conserv. 33: 147-164.

Weibull A., Bengtsson J. \& Nohlgren E. 2000: Diversity of butterflies in the agricultural landscape: the role of farming system and landscape heterogeneity. - Ecography 23: 743-750.

Wikström L., Milberg P. \& Bergman K.-O. 2009: Monitoring of butterflies in semi-natural grasslands: Diurnal variation and weather effects. - J. Insect Conserv. 13: 203-211.

Willott S.J., Lim D.C., Cомpton S.G. \& Sutton S.G. 2000: Effects of selective logging on the butterflies of a Bornean rainforest. - Conserv. Biol. 14: 1055-1065.

Winfree R., Bartomeus I. \& Cariveau D.P. 2011: Native pollinators in anthropogenic habitats. - Annu. Rev. Ecol. Evol. Syst. 42: 1-22.

Yamaura Y., Ikeno S., Sano M., Okabe K. \& Ozaki K. 2009: Bird responses to broad-leaved forest patch area in a plantation landscape across seasons. - Biol. Conserv. 142: 2155-2165.

Yamaura Y., OKa H., Taki H., OZaKi K. \& Tanaka H. 2012: Sustainable management of planted landscapes: lessons from Japan. - Biodiv. Conserv. 21: 3107-3129.

Zuur A.F., Ieno E.N. \& Smith G.M. (eds) 2007: Analyzing Ecological Data. Springer, New York, 672 pp.

Zuur A.F., Ieno E.N., Walker N.J., SAveliev A.A. \& Smith G.M. 2009: Mixed Effects Models and Extensions in Ecology in R. Springer, New York, 524 pp.

Received August 3, 2017; revised and accepted November 24, 2017 Published online December 7, 2017 
Table S1. Characteristics of the study sites.

\begin{tabular}{|c|c|c|c|c|c|c|c|c|c|c|c|c|c|c|}
\hline \multirow[b]{2}{*}{ Site } & \multirow{2}{*}{$\begin{array}{l}\text { Dominant canopy } \\
\text { tree }(\%)^{a}\end{array}$} & \multirow{2}{*}{$\begin{array}{l}\text { Elevation } \\
\quad(\mathrm{m})\end{array}$} & \multirow{2}{*}{$\begin{array}{l}\text { Size } \\
\text { (ha) }\end{array}$} & \multirow{2}{*}{ Age } & \multirow{2}{*}{$\begin{array}{l}\text { Canopy } \\
\text { height } \\
\text { (m) }\end{array}$} & \multicolumn{3}{|c|}{ Stem density } & \multirow{2}{*}{$\begin{array}{l}\text { Mean dbh } \\
\text { of canopy } \\
\text { stems } \mathrm{cm} \text { ) }\end{array}$} & \multirow{2}{*}{$\begin{array}{c}\text { Percentage } \\
\text { of dedicuous } \\
\text { tree }^{b}\end{array}$} & \multirow{2}{*}{$\begin{array}{c}\text { Flower } \\
\text { plant } \\
\text { richness }\end{array}$} & \multirow{2}{*}{$\begin{array}{c}\text { Host } \\
\text { plant } \\
\text { richness }\end{array}$} & \multirow{2}{*}{$\begin{array}{l}\text { Canopy } \\
\text { openness }\end{array}$} & \multirow{2}{*}{$\begin{array}{l}\text { Distance } \\
\text { to forest } \\
\text { edge }(\mathrm{m})\end{array}$} \\
\hline & & & & & & Canopy & $\begin{array}{l}\text { Sub- } \\
\text { canopy }\end{array}$ & Shrub & & & & & & \\
\hline \multicolumn{15}{|c|}{ Plantation forests } \\
\hline PAB1 & $\begin{array}{c}\text { Abies veitchii }(97.6) \\
\text { Alnus hirsuta (2.4) }\end{array}$ & 1555 & 3.75 & 32 & 10 & 25 & 13 & 2 & 20.1 & 0.068 & 21 & 23 & 26.22 & 470 \\
\hline PAB2 & $\begin{array}{l}\text { Abies veitchii (55.0) } \\
\text { Larix kaempferi (37.5) }\end{array}$ & 1390 & 12.3 & 48 & 16 & 40 & 7 & 12 & 29.4 & 0.489 & 10 & 30 & 8.56 & 596 \\
\hline PLA1 & $\begin{array}{c}\text { Larix kaempferi (79.2) } \\
\text { Carpinus tschonoskii (8.3) }\end{array}$ & 1029 & $>10$ & $46-57$ & 24 & 24 & 2 & 1 & 29.2 & 0.923 & 13 & 22 & 10.84 & 101 \\
\hline PLA2 & $\begin{array}{c}\text { Larix kaempferi (81.8) } \\
\text { Carpinus tschonoskii (4.5) }\end{array}$ & 1372 & 3.5 & 32 & 12 & 22 & 34 & 1 & 21.1 & 0.982 & 39 & 36 & 28.18 & 27 \\
\hline PLA3 & $\begin{array}{l}\text { Larix kaempferi (80.0) } \\
\text { Quercus serrata }(10.0)\end{array}$ & 1089 & 9.2 & 80 & 23 & 20 & 17 & 37 & 35.7 & 1 & 14 & 31 & 8.32 & 430 \\
\hline PLA4 & $\begin{array}{c}\text { Larix kaempferi (73.7) } \\
\text { Carpinus tschonoskii (10.5) }\end{array}$ & 1194 & 11.7 & 65 & 20 & 19 & 7 & 26 & 29.3 & 1 & 9 & 22 & 4.02 & 206 \\
\hline PRP1 & $\begin{array}{l}\text { Pinus densiflora (79.4) } \\
\text { Larix kaempferi (14.7) }\end{array}$ & 959 & 29.5 & 62 & 17 & 34 & 1 & 6 & 32.5 & 0.229 & 10 & 28 & 11.24 & 479 \\
\hline PRP2 & $\begin{array}{c}\text { Pinus densiflora (72.7) } \\
\text { Carpinus tschonoskii (12.1) }\end{array}$ & 965 & 3.72 & $>65$ & 24 & 33 & 11 & 32 & 29.9 & 0.318 & 10 & 27 & 4.54 & 96 \\
\hline \multicolumn{15}{|c|}{ Natural forests } \\
\hline NDE1 & $\begin{array}{l}\text { Carpinus tschonoskii (34.8) } \\
\text { Castanea crenata (17.4) }\end{array}$ & 1052 & 3.51 & $>57$ & 16 & 23 & 20 & 94 & 28.9 & 0.977 & 11 & 33 & 5.18 & 135 \\
\hline NDE2 & $\begin{array}{l}\text { Quercus serrata (52.4) } \\
\text { Pinus densiflora (19.0) }\end{array}$ & 1030 & $>60$ & $46-56$ & 20 & 21 & 16 & 39 & 30.1 & 0.838 & 20 & 43 & 6.20 & 142 \\
\hline NDE3 & $\begin{array}{l}\text { Carpinus tschonoskii (26.7) } \\
\text { Quercus mongolica (15.6) }\end{array}$ & 1128 & 3.35 & $>200$ & 18 & 45 & 40 & 46 & 21.4 & 0.894 & 5 & 25 & 5.00 & 635 \\
\hline NDE4 & $\begin{array}{l}\text { Quercus mongolica (27.3) } \\
\text { Pinus densiflora (18.2) }\end{array}$ & 973 & $>30$ & 40 & 15 & 22 & 31 & 84 & 26.4 & 0.925 & 21 & 48 & 9.78 & 215 \\
\hline NMI1 & $\begin{array}{c}\text { Chamaecyparis obtusa } \\
\text { (32.4) } \\
\text { Tsuga sieboldii (26.5) }\end{array}$ & 928 & 318 & $>200$ & 17 & 34 & 29 & 37 & 25.8 & 0.302 & 0 & 22 & 4.48 & 106 \\
\hline NMI2 & $\begin{array}{c}\text { Chamaecyparis obtusa } \\
(50.0) \\
\text { Tsuga sieboldii (9.1) }\end{array}$ & 1070 & $>540$ & $>200$ & 17 & 44 & 21 & 53 & 26.7 & 0.369 & 1 & 12 & 3.58 & 1270 \\
\hline NRP1 & $\begin{array}{c}\text { Pinus densiflora (87.5) } \\
\text { Carpinus tschonoskii (5.0) }\end{array}$ & 1036 & 146 & $>100$ & 24 & 40 & 41 & 82 & 28.2 & 0.333 & 3 & 20 & 5.80 & 200 \\
\hline NRP2 & $\begin{array}{l}\text { Pinus densiflora (55.2) } \\
\text { Quercus serrata (10.3) }\end{array}$ & 916 & 18.7 & $>120$ & 18 & 29 & 31 & 72 & 29.8 & 0.583 & 5 & 31 & 4.84 & 201 \\
\hline
\end{tabular}

a Only the two most dominant tree species are shown. The percentages of each species are calculated based on the number of stems. For two or more species that had the same number of stems, the species with larger basal area are shown. ${ }^{b}$ The percentage of the deciduous species is calculated based on the number of stems of the canopy and subcanopy trees. ${ }^{c}$ Canopy openness is the average of the lightest five values among the ten values per site.

Table S2. List of butterfly species observed in each site with reference to the host plants.

\begin{tabular}{|c|c|c|c|c|c|c|c|c|c|c|c|c|c|c|c|c|c|}
\hline Family/Species & Host plant & PAB1 & PAB2 & PLA1 & PLA2 & PLA3 & PLA4 & PRP1 & PRP2 & NDE1 & NDE2 & NDE3 & 3 NDE4 & NMI1 & NMI2 & NRP1 & NRP2 \\
\hline \multicolumn{18}{|l|}{ Papilionidae } \\
\hline Parnassius citrinarius & Herb & 0 & 0 & 2 & 0 & 0 & 0 & 0 & 0 & 0 & 0 & 0 & 1 & 0 & 0 & 0 & 0 \\
\hline Papilio dehaanii & Tree & 0 & 0 & 0 & 0 & 0 & 0 & 0 & 0 & 0 & 0 & 0 & 0 & 0 & 0 & 1 & 0 \\
\hline \multicolumn{18}{|l|}{ Pieridae } \\
\hline Pieris $m / n$ & Herb & 3 & 1 & 5 & 4 & 3 & 1 & 0 & 0 & 1 & 0 & 0 & 8 & 0 & 0 & 0 & 0 \\
\hline Eurema mandarina & Herb (shrub) & 0 & 0 & 0 & 1 & 0 & 0 & 0 & 0 & 0 & 0 & 0 & 0 & 0 & 0 & 0 & 0 \\
\hline Gonepteryx aspasia & Tree & 0 & 0 & 0 & 0 & 0 & 0 & 0 & 0 & 1 & 0 & 0 & 0 & 0 & 0 & 0 & 0 \\
\hline \multicolumn{18}{|l|}{ Lycaenidae } \\
\hline Curetis acuta & Tree & 0 & 0 & 0 & 0 & 0 & 0 & 0 & 1 & 0 & 0 & 0 & 0 & 0 & 0 & 0 & 0 \\
\hline Narathura japonica & Tree & 0 & 0 & 0 & 1 & 0 & 0 & 0 & 0 & 0 & 0 & 0 & 0 & 0 & 0 & 0 & 0 \\
\hline Artopoetes pryeri & Tree & 1 & 1 & 0 & 0 & 0 & 0 & 0 & 0 & 0 & 0 & 0 & 4 & 0 & 0 & 0 & 0 \\
\hline Antigius attilia & Tree & 0 & 0 & 0 & 0 & 0 & 0 & 0 & 0 & 0 & 2 & 0 & 0 & 0 & 0 & 0 & 0 \\
\hline Araragi enthea & Tree & 0 & 0 & 0 & 0 & 0 & 0 & 0 & 0 & 0 & 0 & 0 & 1 & 0 & 0 & 0 & 0 \\
\hline Chrysozephyrus smaragdinus & Tree & 0 & 0 & 0 & 0 & 0 & 0 & 0 & 0 & 0 & 0 & 0 & 0 & 0 & 0 & 2 & 0 \\
\hline Favonius jezoensis & Tree & 0 & 0 & 0 & 0 & 0 & 0 & 0 & 0 & 0 & 0 & 0 & 1 & 0 & 0 & 0 & 0 \\
\hline Favonius orientalis & Tree & 0 & 0 & 0 & 0 & 0 & 0 & 0 & 0 & 0 & 0 & 0 & 0 & 0 & 0 & 1 & 0 \\
\hline Strymonidia mera & Tree & 0 & 0 & 0 & 0 & 0 & 0 & 0 & 0 & 3 & 0 & 0 & 0 & 0 & 0 & 0 & 0 \\
\hline Celastrina argiolus & Tree/herb & 0 & 0 & 0 & 0 & 0 & 0 & 0 & 0 & 0 & 1 & 0 & 0 & 0 & 0 & 0 & 0 \\
\hline Celastrina sugitanii & Tree & 0 & 0 & 0 & 0 & 0 & 0 & 0 & 0 & 0 & 2 & 0 & 0 & 0 & 0 & 0 & 0 \\
\hline \multicolumn{18}{|l|}{ Nymphalidae } \\
\hline Parantica sita & Herb & 0 & 1 & 1 & 2 & 1 & 2 & 0 & 0 & 0 & 0 & 0 & 1 & 0 & 0 & 0 & 0 \\
\hline Argynnis paphia & Herb & 9 & 0 & 0 & 7 & 2 & 0 & 2 & 0 & 0 & 0 & 0 & 10 & 0 & 0 & 0 & 0 \\
\hline Argyronome ruslana & Herb & 0 & 0 & 0 & 1 & 0 & 0 & 0 & 0 & 0 & 0 & 0 & 0 & 0 & 0 & 0 & 0 \\
\hline Damora sagana & Herb & 0 & 0 & 0 & 0 & 0 & 0 & 0 & 0 & 0 & 0 & 0 & 3 & 0 & 0 & 0 & 0 \\
\hline Fabriciana adippe & Herb & 0 & 0 & 0 & 1 & 0 & 0 & 0 & 0 & 0 & 0 & 0 & 0 & 0 & 0 & 0 & 0 \\
\hline Nephargynnis anadyomene & Herb & 0 & 0 & 0 & 0 & 0 & 0 & 0 & 0 & 0 & 0 & 0 & 1 & 0 & 0 & 0 & 0 \\
\hline Ladoga camilla & Tree & 0 & 0 & 0 & 0 & 0 & 0 & 1 & 0 & 0 & 0 & 0 & 0 & 0 & 0 & 0 & 0 \\
\hline Neptis sappho & Tree/herb & 0 & 0 & 0 & 0 & 0 & 0 & 0 & 0 & 0 & 0 & 0 & 0 & 0 & 0 & 0 & 1 \\
\hline Nymphalis xanthomelas & Tree & 1 & 0 & 0 & 1 & 1 & 0 & 0 & 0 & 0 & 1 & 0 & 0 & 0 & 0 & 0 & 0 \\
\hline Libythea lepita & Tree & 2 & 4 & 0 & 5 & 3 & 2 & 0 & 0 & 2 & 1 & 2 & 5 & 2 & 0 & 3 & 0 \\
\hline Lethe diana & Bamboo grass & 0 & 0 & 0 & 0 & 0 & 0 & 0 & 0 & 0 & 0 & 0 & 1 & 0 & 0 & 0 & 0 \\
\hline Neope niphonica & Bamboo grass & 0 & 1 & 0 & 0 & 1 & 0 & 0 & 0 & 0 & 0 & 1 & 0 & 0 & 0 & 0 & 0 \\
\hline Ypthima argus & Grass & 1 & 1 & 0 & 14 & 8 & 0 & 0 & 0 & 0 & 0 & 0 & 3 & 0 & 0 & 0 & 0 \\
\hline Zophoessa callipteris & Bamboo grass & 0 & 1 & 0 & 0 & 0 & 0 & 0 & 0 & 0 & 0 & 0 & 0 & 0 & 0 & 0 & 0 \\
\hline \multicolumn{18}{|l|}{ Hesperiidae } \\
\hline Erynnis montanus & Tree & 0 & 0 & 0 & 0 & 0 & 0 & 0 & 0 & 0 & 0 & 0 & 1 & 0 & 0 & 0 & 0 \\
\hline Ochlodes ochraceus & Grass & 0 & 1 & 2 & 8 & 1 & 0 & 1 & 0 & 0 & 0 & 0 & 3 & 0 & 0 & 0 & 0 \\
\hline Parnara guttata & Grass & 2 & 0 & 0 & 2 & 0 & 0 & 0 & 0 & 0 & 0 & 0 & 0 & 0 & 0 & 0 & 0 \\
\hline
\end{tabular}


Table S3. Pearson's correlation coefficients among the environmental variables. The significant relationships $(P<0.05)$ were shown in bold.

\begin{tabular}{|c|c|c|c|c|c|c|c|c|c|c|c|c|c|}
\hline & $\begin{array}{c}\text { Canopy } \\
\text { stem } \\
\text { density }\end{array}$ & $\begin{array}{l}\text { Subcanopy } \\
\text { stem } \\
\text { density }\end{array}$ & $\begin{array}{c}\text { Shrub } \\
\text { stem } \\
\text { density }\end{array}$ & $\begin{array}{c}\text { Canopy } \\
\text { DBH }\end{array}$ & $\begin{array}{c}\text { Tree } \\
\text { species } \\
\text { richness }\end{array}$ & $\begin{array}{c}\text { Flower } \\
\text { abundance }\end{array}$ & $\begin{array}{c}\text { Flower } \\
\text { plant } \\
\text { richness }\end{array}$ & $\begin{array}{c}\text { Total } \\
\text { host } \\
\text { plant } \\
\text { richness }\end{array}$ & $\begin{array}{c}\text { Percentage } \\
\text { of } \\
\text { deciduous } \\
\text { trees }\end{array}$ & $\begin{array}{l}\text { Percentag } \\
\text { of } \\
\text { coniferous } \\
\text { trees } \\
\end{array}$ & $\begin{array}{l}\text { Canopy } \\
\text { openness }\end{array}$ & S Altitu & $\begin{array}{c}\text { Distance } \\
\text { to forest } \\
\text { edge }\end{array}$ \\
\hline Canopy stem density & 1 & -0.112 & 0.264 & 0.161 & 0.355 & -0.592 & -0.615 & -0.337 & -0.185 & -0.145 & -0.598 & -0.436 & 0.371 \\
\hline Subcanopy stem density & & 1 & 0.338 & -0.740 & 0.220 & 0.140 & 0.127 & 0.028 & -0.125 & -0.353 & 0.335 & 0.261 & 0.030 \\
\hline Shrub stem density & & & 1 & 0.134 & 0.800 & -0.438 & -0.368 & 0.199 & 0.173 & -0.799 & -0.559 & -0.523 & -0.027 \\
\hline Canopy DBH & & & & 1 & 0.169 & -0.383 & -0.304 & 0.102 & 0.126 & 0.012 & -0.538 & -0.529 & -0.076 \\
\hline Tree species richness & & & & & 1 & -0.430 & -0.322 & 0.345 & 0.381 & -0.843 & -0.651 & -0.531 & -0.087 \\
\hline Flower abundance & & & & & & 1 & 0.967 & 0.466 & 0.326 & 0.253 & 0.866 & 0.497 & -0.361 \\
\hline Flower plar & & & & & & & 1 & 0.614 & 0.370 & 0.144 & 0.809 & 0.499 & -0.369 \\
\hline Total host & & & & & & & & 1 & 0.473 & -0.411 & 0.180 & -0.082 & -0.478 \\
\hline Percentage of deciduous trees & & & & & & & & & 1 & -0.525 & -0.071 & -0.068 & -0.301 \\
\hline Percentage of coniferous trees & & & & & & & & & & 1 & 0.486 & 0.458 & 0.113 \\
\hline Canopy openness & & & & & & & & & & & 1 & 0.712 & -0.147 \\
\hline Altitude & & & & & & & & & & & & 1 & 0.184 \\
\hline Distance to forest edge & & & & & & & & & & & & & \\
\hline
\end{tabular}

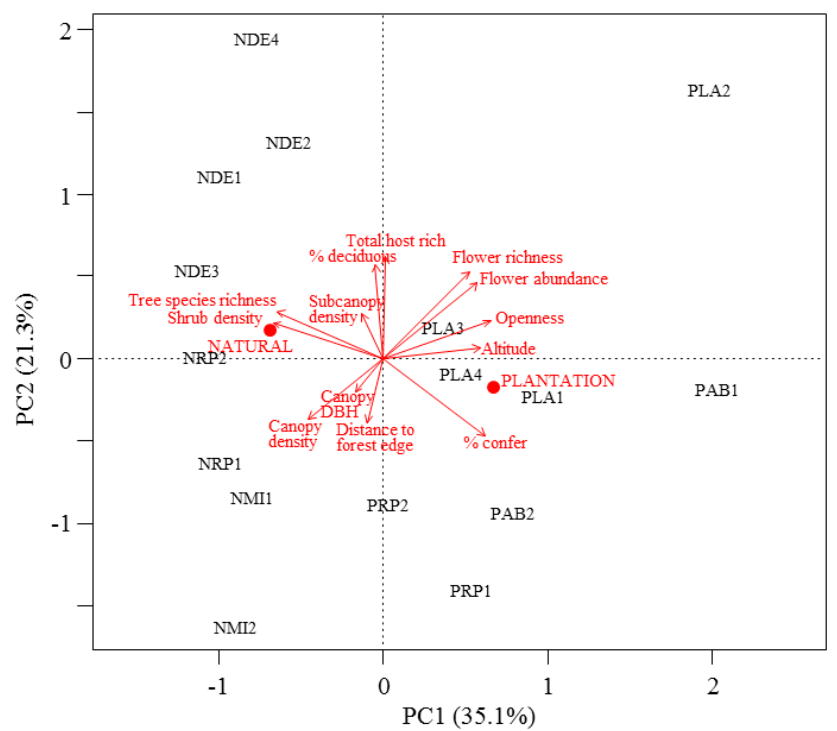

Fig. S1 (left). A biplot of Principal Component Analysis (PCA) showing the relationships among the environmetal variables. The environmental variables and sites were shown in red and black, respectively. For the environmental variables, plantations or natural forests (a categorical variable) are shown as solid circels, whereas continuous variables were shown as arrows.
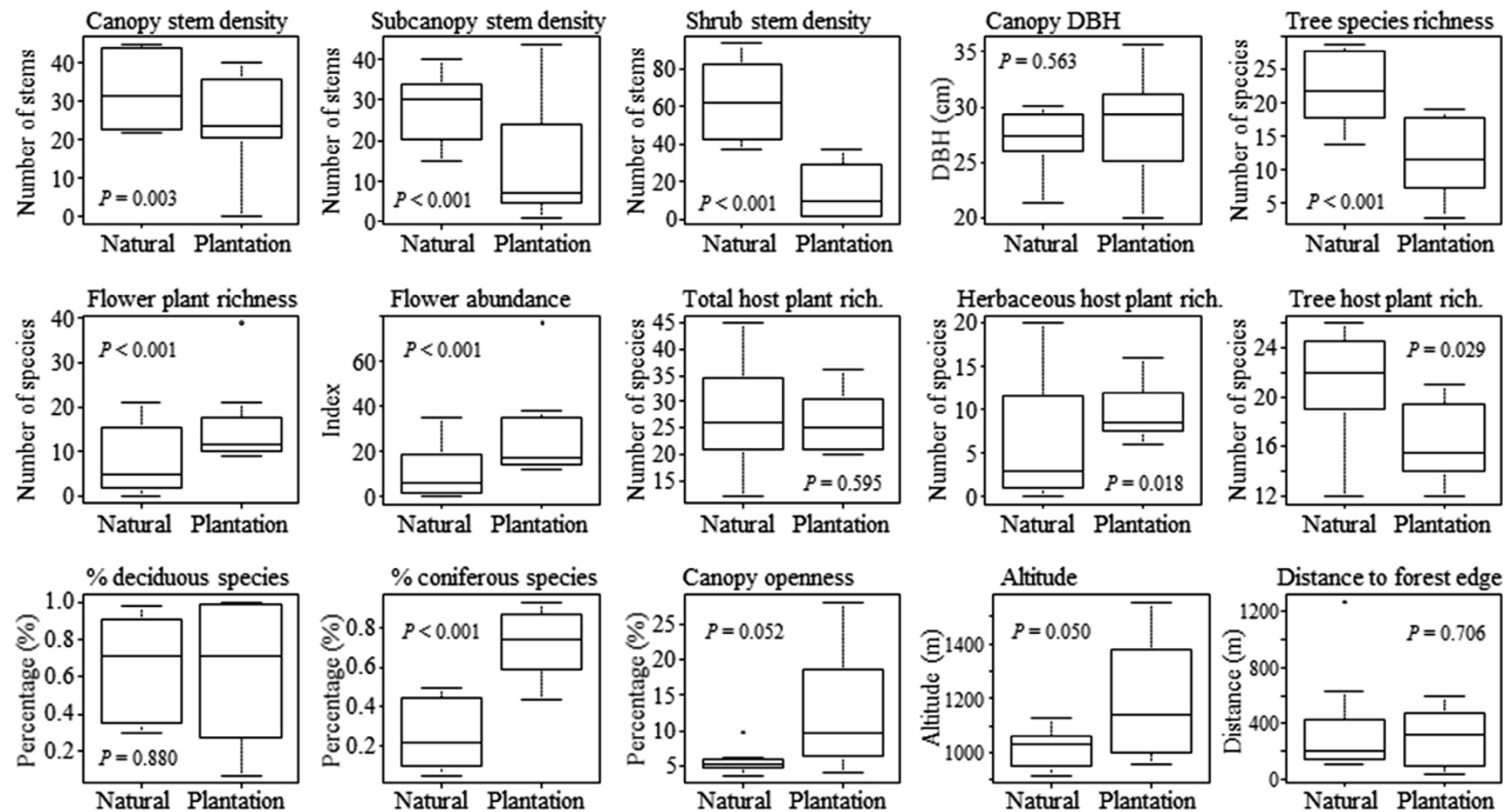

Natural Plantation

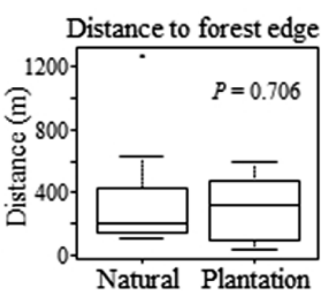

Fig. S2. Comparison of 15 environmental variables between plantations and natural forests. The significant differences between plantations and natural forests were tested using the generalized linear models. For the variables with count data (number of stems or number of species), a Poisson error distribution was assumed, whereas for the other variables, a Gaussian error was assumed. 